\title{
Editorial Revista Chilena de Antropología: Un largo camino
}

Este número de la Revista Chilena de Antropología nos brinda la oportunidad de celebrar los sesenta años de la institucionalización de la Antropología como disciplina en la Universidad de Chile. Si bien el acto administrativo que creó el Centro de Estudios Antropológicos no da cuenta de los eventos previos que condujeron a él, como usualmente sucede a los procesos que conducen a la conformación de instituciones, podemos fijar la existencia formal de la disciplina en esta universidad, a partir del 30 de Octubre de 1954 al decretarse por parte del Rector (D.U. 3510) la formación del Centro, dependiente de la misma rectoría, con la misión de desarrollar la Antropología, en el sentido más amplio, en la Universidad de Chile, generando un espacio académico para la investigación y la conformación de un cuerpo de futuros docentes para ello.

Nuestro propósito aquí no es hacer una sinopsis histórica del desarrollo de la Antropología en nuestra Universidad, sino que, como se señala al principio, celebrar estos sesenta años de existencia, en los cuales las tareas encomendadas a los fundadores del Centro de Estudios Antropológicos de la Universidad de Chile, y las que se fueron agregando en el largo camino recorrido hasta hoy, han ido siendo cumplidas y ampliadas, contribuyendo significativamente en este proceso a la consolidación institucional de la disciplina en el país.

Desde unos comienzos más bien humildes, dos habitaciones en el Museo Pedagógico, en la calle Dieciocho en el centro de Santiago, para acoger al reducido grupo de entusiastas pioneros, aglutinados en torno al proyecto de investigación "Reconocimiento Arqueológico de Chile" que impulsaba el Dr. Richard Schaedel, -antropólogo social y antropólogo físico que se desempeñaba como profesor visitante de la entonces Facultad de Filosofía y Educación de nuestra casa de estudios-,sumado a la pasión de éstos primeros estudiosos,se fue forjando la Antropología en la Universidad de Chile, con decisivos aportes al desarrollo de la disciplina en el país, permitiendo alcanzar la actual etapa de expansión de esta.

El Centro de Estudios Antropológicos desarrolló una prolífica labor durante su existencia como tal, producción que suele ser omitida o minimizada por quienes han publicado síntesis históricas sobre la disciplina, o de una rama de ésta en nuestro país, pudiendo explicarse esto en lo joven que es aun el ejercicio de ella o de lo contrario debiéramos buscar dicha explicación en un contexto psicoanalitico. La producción del centro puede aquilatarse mejor si revisamos las diversas publicaciones, revistas, artículos y documentos de trabajo, muchos de los cuales son aportes innovadores a la disciplina en su época o constituyen iniciativas pioneras en nuestro país y en algunos casos en un ámbito mayor.

El camino hasta hoy no estuvo exento de dificultades. Recursos limitados, cambios en la dependencia institucional, una permanente transhumancia en instalaciones no adecuadas, no contuvieron el interés y los esfuerzos por hacer crecer la disciplina en 
una perspectiva que desde sus orígenes fue trans e interdisciplinaria. Las interacciones con académicos y estudiante de otras facultades, su inserción en la facultad de Filosofía y Educación, -en el departamento de Ciencias Sociales-, el interés de estudiantes de Historia, Filosofía y otras carreras, propiciaron las condiciones que hicieron posible la transformación del centro en el actual Departamento de Antropología a fines de los sesenta y que se materializó en 1970 regularizando la formación de antropólogos(as) y arqueólogos (as) en adelante.

El entusiasmo con que inició el Departamento la nueva etapa fue interrumpido por el golpe militar en 1973. Si bien ésto no significó el cierre del departamento, como sucedió con otras unidades y carreras de la universidad, obligó a muchos dejar el país se impuso un clima de sospechas, importantes restricciones a la libertad académica, serias limitaciones presupuestarias y nuevos episodios de transhumancia y de cambios forzados en la organización y dependencia institucional. Esto tuvo serios impactos sobre el trabajo académico, en especial sobre las condiciones de la docencia y el patrimonio preservado por el Departamento.

Concluida la obscura etapa de la dictadura militar, a partir de 1990 se empieza muy lentamente a recuperar la normalidad académica, sin que esto significará en absoluto la restitución de los recursos expoliados por ésta y, en muchos casos, en democracia aumentaron las restricciones y carencias que sólo empezaron a modificarse gradualmente con la construcción de las actuales dependencias de la Facultad de Ciencias Sociales, unidad académica a la que pertenece actualmente el departamento.

Los últimos diez años han sido un período de renovación académica, expansión de la comunidad académica y de los recursos, en gran parte autogenerados, en esta paradojal y bizarra situación de ser una universidad pública en que la mayor parte de nuestros recursos son generados por nosotros y no por el Estado. Esta renovación y crecimiento no sólo son reflejo de la robustez de la Antropología en nuestra institución, si no que, de la gran resiliencia de ella frente a las múltiples condiciones adversas que ha debido enfrentar en este largo camino recorrido. Hoy nuestra Facultad está construyendo un nuevo edificio que se agrega al actual, incorporando nuevas áreas de trabajo, laboratorios, espacios para la preservación del patrimonio y otros que potenciarán, como nunca, nuestra labor académica en sus distintas dimensiones. Nuestro contingente de académicos ha crecido significativamente, y lo seguirá haciendo, a fin de brindar a nuestros estudiantes las mejores condiciones de formación y a la sociedad un conocimiento antropológico acorde a los requerimientos contemporáneos.

Nuestro departamento no puede si no celebrar con entusiasmo estos sesenta años en que la visión que inspiró impulsar la Antropología en la Universidad de Chile, al servicio del desarrollo de esta y del país, se ha logrado llevar a cabo con un éxito que tal vez quienes iniciaron este largo camino, en permanente construcción, ni siquiere soñaron y que, creo, les llenaría de orgullo.

Eugenio Aspillaga

Director Departamento de Antropología Santiago, 2 de Octubre de 2014. 